Molecules 2001, 6, 639-646

molecules

ISSN 1420-3049

http://www.mdpi.org

\title{
Electrochemical Study of Bromide in the Presence of 1,3- Indandione. Application to the Electrochemical Synthesis of Bromo Derivatives of 1,3-Indandione
}

\author{
D. Nematollahi*, N. Akaberi \\ Department of Chemistry, Faculty of Science, University of Bu-Ali-Sina, Hamadan, Iran
}

*Author to whom correspondence should be addressed: E-mail: nemat@basu.ac.ir

Received: 15 November 2000; in revised form 7 June 2001 / Accepted: 8 June 2001/ Published: 30 June 2001

\begin{abstract}
The electrochemical oxidation of bromide in the presence of 1,3-indandione (1) in water/acetic acid and methanol/acetic acid mixtures has been studied by cyclic voltammetry and controlled-potential coulometry. The results indicate the participation of 1,3-indandione in the bromination reaction. On the basis of the electroanalytical and preparative results a reaction mechanism including electron transfer, chemical reaction and regeneration of bromide was discussed. The electrochemical synthesis of bromo derivatives of 1,3-indandione (2-3) has been successfully performed at constant current, in an undivided cell, in good yield and purity.
\end{abstract}

Keywords: Electrochemical oxidation, cyclic voltammetry, 1,3-indandione, 2-bromo1,3-indandione, 2,2-dibromo-1,3-indandione.

\section{Introduction}

In previous publications we have shown that electrolysis offers a convenient and simple technique for the synthesis of organic compounds [1-9]. Although numerous methods are available for bromination of 1,3-indandione, they usually involve unstable and/or troublesome reagents such as ascorbic acid for synthesis of 2-bromo-1,3-indandione via reduction of 2,2- 
dibromo-1,3-indandione [10], 5-hydroxy-5-(1,3-indandione-2-yl) barbituric acid and bromine [11], potassium chlorate and bromine [12], the sodium salt of 1,3-indandione-2-sulfonate [13], 2methanoylindandione in the presence of bromine [14], N-bromosuccinimide [15], 2-\{[N(hydroxymethyl)amino]methylene \}-1,3-indandione [16], 2-bromo-2-nitro-1,3-indandione [17], potassium bromate with potassium bromide in the presence of Dowex [18] or the bromine complex of poly(styrene-CO-4-vinyl pyridine)[19], none are satisfactory for the preparation of mono and dibromo derivatives of 1,3-indandione in good yield and purity, under mild conditions such as an electrolytic procedure using bromide salts. This prompted us to investigate the anodic behavior of bromide in the presence of 1,3-indandione by cyclic voltammetry, controlledpotential coulometry and macroscale electrolysis from both electrochemical and organic synthetic aspects. The present work describes an electrochemical study of the anodic oxidation of bromide in the presence of 1,3-indandione in water/acetic acid and methanol/acetic acid mixtures and reports a facile electrochemical method using inexpensive reagents and simple equipment for synthesis of 2-bromo- and 2,2-dibromo-1,3-indandione in good yield and purity.

\section{Results and Discussion}

\section{Electrooxidation of bromide in the presence of 1,3-indandione in water/acetic acid mixture}

The electrochemical oxidation of bromide in the presence of 1,3-indandione (1) in water/acetic acid mixture has been studied using cyclic voltammetry and controlled-potential coulometry. The cyclic voltammogram of $5 \times 10^{-3} \mathrm{M}$ of sodium bromide in aqueous acetic acid $(40 \% \mathrm{~V} / \mathrm{V})$ containing $0.1 \mathrm{M}$ potassium nitrate as supporting electrolyte (scan rate: $50 \mathrm{mV} / \mathrm{s} ; \mathrm{T}=25 \pm 1^{\circ} \mathrm{C}$ ) exhibits anodic and cathodic peaks at $0.98 \mathrm{~V}$ and $0.65 \mathrm{~V}$, respectively, which correspond to the twoelectron transformation of bromide to bromine and vice versa (Figure1, curve a).

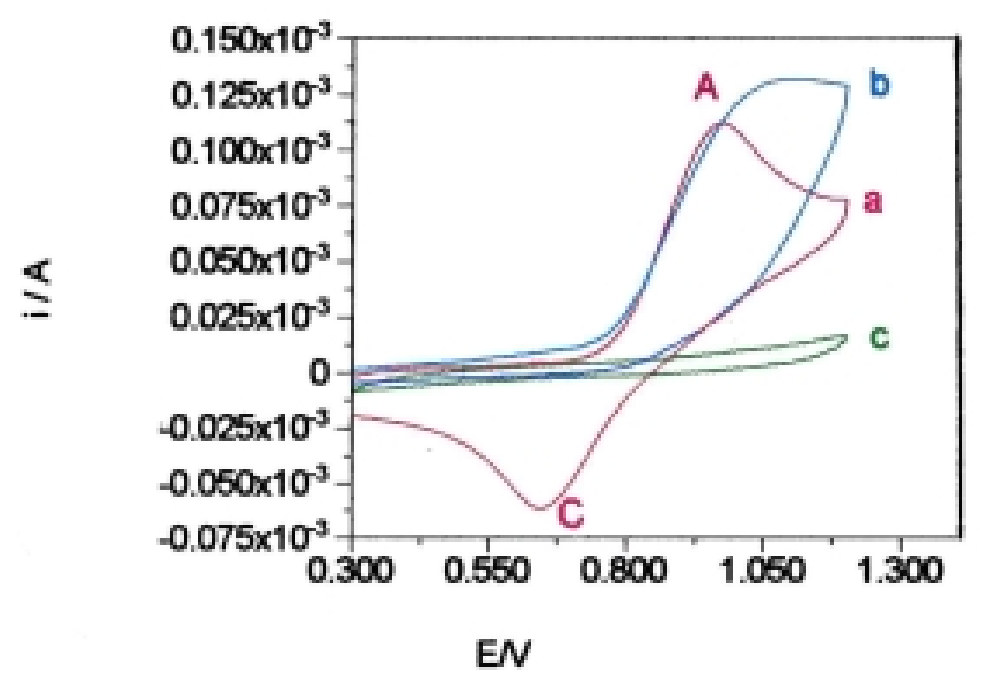

Figure 1. (a) Cyclic voltammogram of $5 \times 10^{-3} \mathrm{M}$ sodium bromide, (b) cyclic voltammogram of $5 \times 10^{-3} \mathrm{M}$ sodium bromide in the presence of $5 \times 10^{-3} \mathrm{M} 1,3$-indandione, (c) cyclic voltammogram of $1 \times 10^{-3}$ M 1,3-indandione. Working electrode: glassy carbon. 
A peak current ratio $\left(\mathrm{I}_{\mathrm{pa}} / \mathrm{I}_{\mathrm{pc}}\right)$ of nearly unity, particularly during the repetitive recycling of potential can be considered as criteria for the stability of bromine produced at the surface of electrode under the experimental conditions. Figure 1, curve b, shows the cyclic voltammogram obtained for $5 \times 10^{-3} \mathrm{M}$ solution of sodium bromide in the presence of $5 \times 10^{-3} \mathrm{M}$ 1,3-indandione. The voltammogram exhibits an increase in anodic current and disappearance of the cathodic counterpart of the anodic peak. Under these conditions a cathodic peak (C) appears proportionally to the increase of sweep rate, and its height increases progressively with scan rate. Moreover, a plot of the peak current function $\left(\mathrm{I}_{\mathrm{pa}} / \mathrm{v}^{1 / 2}\right)$ and peak current ratio $\left(\mathrm{I}_{\mathrm{pa}} / \mathrm{I}_{\mathrm{pc}}\right)$ as a function of scan rate is in good agreement with that of occurrence of a chemical reaction after the electron transfer process appearing as a decrease in the peak current ratio $\left(\mathrm{I}_{\mathrm{pa}} / \mathrm{I}_{\mathrm{pc}}\right)$ and peak current function $\left(\mathrm{I}_{\mathrm{pa}} / \mathrm{v}^{1 / 2}\right)$ with increasing scan rate [20].

In addition, controlled-potential coulometry was performed in solution containing $5 \times 10^{-3} \mathrm{M}$ sodium bromide and $5 \times 10^{-3} \mathrm{M}$ of 1,3-indandione at $1.10 \mathrm{~V}$ vs. SCE. The monitoring of the electrolysis progress was carried out by cyclic voltammetry. It is shown that as the electrolysis proceeds, the height of anodic peak (A) decreases and finally it disappears. These observations allow us to propose the following mechanism for electrochemical oxidation of bromide in the presence of 1,3-indandione (Scheme 1).

$2 \mathrm{Br}^{-}-2 \mathrm{e}^{-} \longrightarrow \mathrm{Br}_{2}$<smiles>O=C1CC(=O)c2ccccc21</smiles>

1

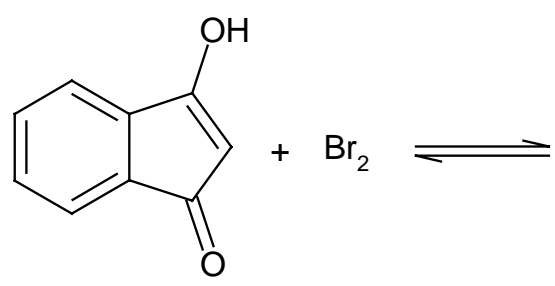

1a

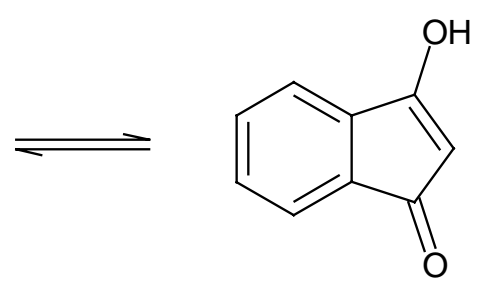

$1 a$

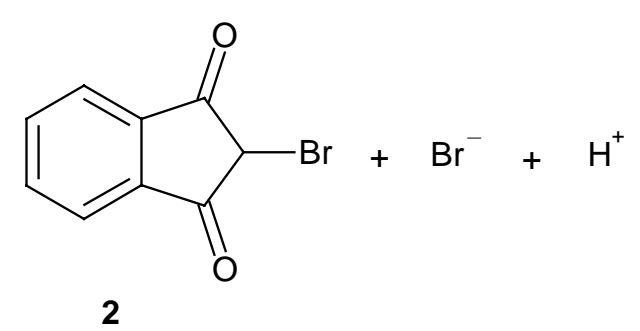

\section{Scheme 1}

Such a mechanism is also in good agreement with the results already proposed for the electrochemical halogenation of dibenzoylmethane [21], dimedone [22] and barbituric acid [23]. The interesting feature of this mechanism, is its similarity to the EC mechanism (following reaction), in respect of the reaction of bromine with 1,3-indandione. On the other hand, regeneration of bromide ion on the surface of electrode indicates its resemblance to EC' mechanism (catalytic reaction). Based on this mechanism, the increase of the $I_{p a}$ in the presence of 1,3- 
indandione (Figure 1, curve b) is related to regeneration of bromide in surface of electrode [20] (Scheme 1, Eq. 2). The overbromination of 2 can be performed in the presence of excess amounts of bromide as shown in Scheme 2.<smiles>O=C1c2ccccc2C(=O)C1Br</smiles>

2<smiles>C#CC(Br)(Br)Br</smiles>

$2 \mathbf{a}$<smiles>O=C1C(Br)=C(O)c2ccccc21</smiles>

$2 \mathbf{a}$

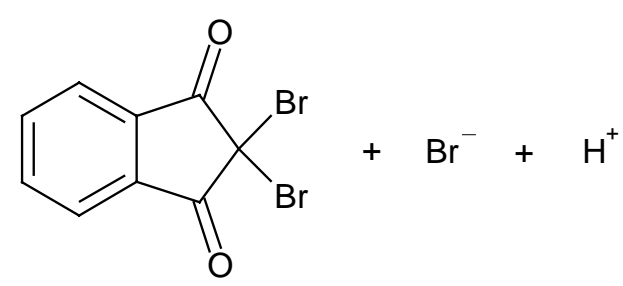

3

\section{Scheme 2}

According to Scheme 2, the initial product in bromination of 1,3-indandione (2), the keto form of 2-bromo-1,3-indandione, is converted into the enol form (2a), which then reacts with a second molecule of bromine. Compounds $\mathbf{2}$ and $\mathbf{3}$ were identified by their IR, ${ }^{1} \mathrm{H}-\mathrm{NMR}$ and ${ }^{13} \mathrm{C}$ NMR spectra, determination of bromine content and melting point. The bromine content in these compounds ( 2 and 3 ) can be determined by the simple method described in the Experimental section. The result shows good agreement between found and required values. A characteristic feature of the electrolysis is that high current density is required to terminate the reaction in short time for the mili mole scale experiment. The purity of $\mathbf{2}$ and $\mathbf{3}$ were unsatisfactory at lower current densities (Table 2) and byproduct(s) were obtained, one of which might be corresponding dimer product. Such a dimer is observed in electrooxidation of acetylacetone [24].

\section{Electrooxidation of bromide in the presence of 1,3-indandione in methanol/acetic acid mixture}

Similar to those of the previous case the cyclic voltammogram representative of the behavior of sodium bromide in $\mathrm{MeOH} / \mathrm{AcOH}(3 \% \mathrm{~V} / \mathrm{V})$ containing $0.1 \mathrm{M} \mathrm{KNO}_{3}$ at $25^{\circ} \mathrm{C}$ exhibits one anodic and corresponding cathodic peak which is corresponding to the transformation of bromide to bromine and vice versa within two-electron process. Fig. 2, curve a, shows the cyclic voltammogram obtained for $5 \times 10^{-3} \mathrm{M}$ solution of bromide in the presence of $5 \times 10^{-3} \mathrm{M} 1,3$ indandione in scan rate $50 \mathrm{mV} / \mathrm{s}$. Under these conditions, the cathodic peak disappeared and voltammogram exhibits an irreversible process, but with decreasing the timescale of experiment, by increasing the sweep rate, the cathodic counterpart (C) of anodic peak (A) become increasingly apparent (Fig. 2 curves b-d). A plot of peak current function $\left(\mathrm{Ipa} / \mathrm{v}^{1 / 2}\right)$ vs. scan rate confirms the 
reaction between bromine and 1,3-indandione, appearing as a decrease in peak current function $\left(\mathrm{Ipa} / \mathrm{v}^{1 / 2}\right)$ with increasing scan rate (Fig. 3). The reaction mechanism and other observations are similar to those of the previous case and we assume such a behavior as an indication of a chemical reaction between bromine and 1,3-indandione according to Scheme 1.

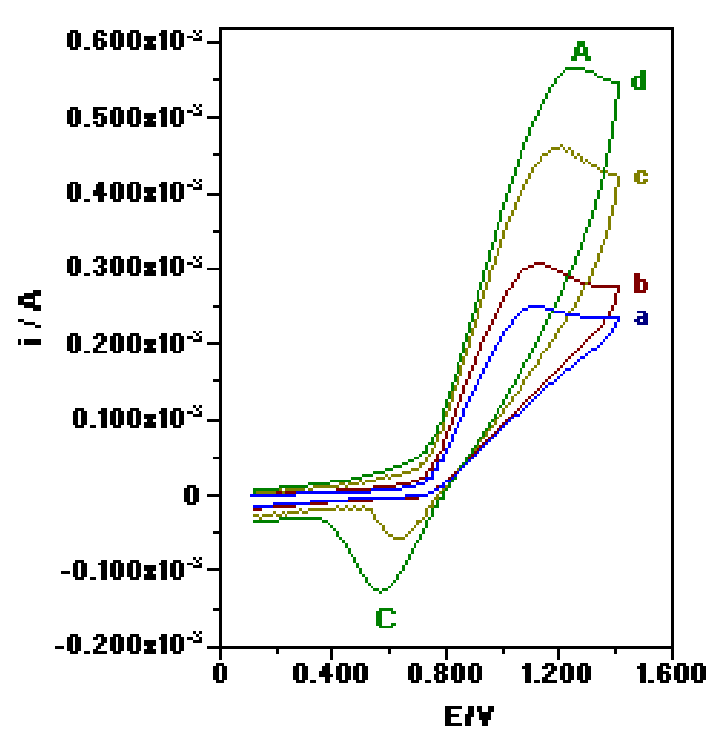

Figure 2. Cyclic voltammograms of $5 \times 10^{-3} \mathrm{M} \mathrm{NaBr}$ in the presence of $5 \times 10^{-3} \mathrm{M} 1,3$-indandione in various potential scan rate at glassy carbon electrode in $\mathrm{MeOH} / \mathrm{AcOH}$ $(3 \%)(\mathrm{V} / \mathrm{V})$. Scan rate from (a) to (d), is: $50,100,300$ and $500 \mathrm{mV} / \mathrm{s}$, respectively. Supporting electrolyte: $0.10 \mathrm{M} \mathrm{KNO}_{3} . \mathrm{T}=25 \pm 1^{\circ} \mathrm{C}$.

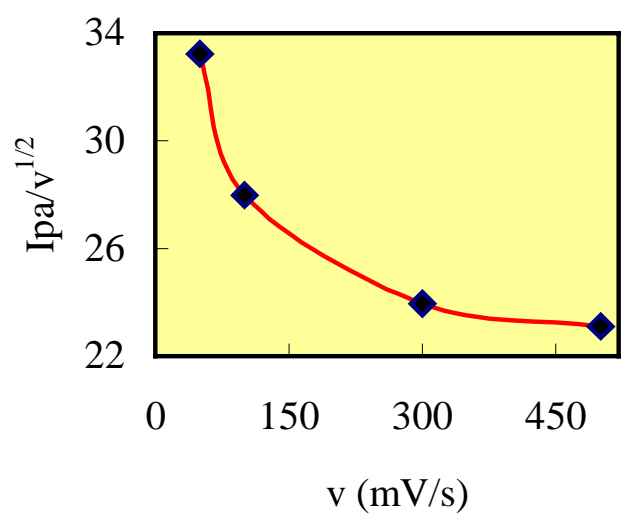

Figure 3. The variation of anodic peak current function $\left(\mathrm{Ipa} / \mathrm{v}^{1 / 2}\right)\left(\mu \mathrm{A} \cdot \mathrm{s}^{1 / 2} \cdot \mathrm{mV}^{-1 / 2}\right)$ vs. scan rate.

\section{Conclusions}

The results of this work show that bromide is oxidized electrochemically to bromine and then reacts with. 1,3-indandione to form $\alpha$-bromo compounds. The reaction mechanisms for anodic oxidation of bromide in the presence of 1,3-indandione are presented in Schemes 1 and 2. We also describe a new facile route for synthesis of 2-bromo and 2,2-dibromo-1,3-indandione, that is 
characterized by: (I) bromination without use of molecular bromine; (II) good control of the rate of release of bromine; (III) selective bromination at the $\alpha$-position of olefinic active methylene compounds and (IV) selective formation of the monobromo or dibromo derivatives in good yields with slight changes in electrolysis conditions. The procedure utilizes inexpensive reagents, simple equipment, and undivided cell,s it is easily carried out, and workup is simple.

\section{Experimental}

Cyclic voltammetry and controlled-potential coulometry were performed using an Autolab model PGSTAT20 potentiostat/galvanostat. The preparative electrolyses were performed using an Iran Electronic Industries 8303 DC power supply. The working electrode used in the voltammetry experiments was a glassy carbon disc and a platinum wire was used as counter electrode. The working electrode potentials were measured versus the SCE electrode (all electrodes from AZAR electrode). Reagent grade 1,3-indandione (Aldrich) and Pro-Analysis grade sodium bromide (E. Merck) were used as received. Proton and carbon spectra were recorded on a JEOL NMRSpectrometer FX 90Q. IR spectra were recorded on a Shimadzu 435 IR spectrophotometer.

\section{General electrolysis procedure}

A solution (ca. $20 \mathrm{~mL}$ ) of sodium bromide and 1,3-indandione (1 mmol) in water/acetic acid or methanol/acetic acid (see Table 1) was electrolyzed in an undivided cell equipped with $\mathrm{C}$-anode (an assembly of four rods, $4 \mathrm{~mm}$ diameter and $12 \mathrm{~mm}$ length) and Fe-cathode $(10 \mathrm{~mm}$ width and 20 mm length) at $25^{\circ} \mathrm{C}$ under constant current density $50 \mathrm{~mA} \mathrm{Cm}{ }^{-2}$ until the quantity of the electricity indicated in Table 1 was passed. At the end of electrolysis, the reaction mixture was diluted with a ca. two-fold volume of water and placed in a cold water bath. The precipitated solid was filtrated, washed, dried and recrystallized from methanol/water mixture $(80 \% \mathrm{~V} / \mathrm{V})$. The recrystallized products gave satisfactory IR, ${ }^{1} \mathrm{H}-\mathrm{NMR},{ }^{13} \mathrm{C}-\mathrm{NMR}$ spectra and analyses of bromine content.

\section{Characterization of the products}

2-Bromo-1,3-indandione (2); m.p. $118-20^{\circ} \mathrm{C}$ (dec.) (Lit.[15]: $\left.117-19^{\circ} \mathrm{C}\right) . \mathrm{IR}_{(\mathrm{KBr})}: v_{\max }=585(\mathrm{C}-$ $\mathrm{Br}), 1615,1721(\mathrm{C}=\mathrm{O}) .{ }^{1} \mathrm{H}-\mathrm{NMR}, \delta \mathrm{ppm}\left(\mathrm{CDCl}_{3}\right): 4.14(\mathrm{H}, \mathrm{s},-\mathrm{CHBr}-)$, 7.61-8.08 (4H, m, -CH-). ${ }^{13} \mathrm{C}-\mathrm{NMR}, \delta \mathrm{ppm}\left(\mathrm{CDCl}_{3}\right): 31.06(-\mathrm{CHBr}-)$ 123.12, 125.63, 137.84 (aromatic carbons), 204.1 $(\mathrm{C}=\mathrm{O})$.

2,2-Dibromo-1,3-indandione (3); m.p. $181-182^{\circ} \mathrm{C}$ (dec). (Lit.[18]: $\left.182-182.5^{\circ} \mathrm{C}\right) . \mathrm{IR}_{(\mathrm{KBr})}$ : $v_{\max }=$ $590(\mathrm{C}-\mathrm{Br}), 1701,1736(\mathrm{C}=\mathrm{O}) .{ }^{1} \mathrm{H}-\mathrm{NMR}, \delta \mathrm{ppm}\left(\mathrm{CDCl}_{3}\right): 8.04(4 \mathrm{H}, \mathrm{m}$, aromatic protons $),{ }^{13} \mathrm{C}-$ NMR, $\delta$ ppm (CDCl): 51.26(-CBrBr-) 125.71, 135.49, 137.97 (aromatic carbons), $209.22(\mathrm{C}=\mathrm{O})$ 
Determination of bromine content [21]

The sample (about $15 \mathrm{mg}$ ) was dissolved in THF and/or chloroform (ca. $10 \mathrm{~mL}$ ) to which aqueous $0.3 \mathrm{M}$ potassium iodide $(5 \mathrm{~mL})$ and aqueous $1 \mathrm{M}$ hydrochloric acid $(5 \mathrm{~mL})$ were added and the liberated iodine (Scheme 3) was titrated with aqueous $0.01 \mathrm{M}$ sodium thiosulphate.<smiles>O=C1c2ccccc2C(=O)C1Br</smiles>

2

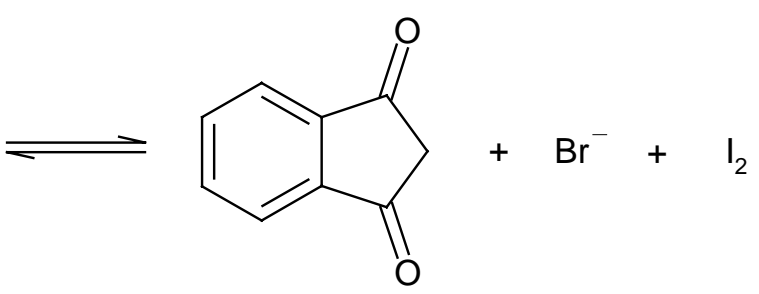

1

Scheme 3

Table 1. Electroanalytical and preparative data.

\begin{tabular}{|c|c|c|c|cc|c|}
\hline Conversion & $\begin{array}{c}\mathrm{NaBr} \\
\mathrm{mmol}\end{array}$ & $\begin{array}{c}\text { Electricity } \\
\text { Passed } \\
\left(\mathrm{F} \mathrm{mol}^{-1}\right)\end{array}$ & $\begin{array}{c}\text { Electrolysis } \\
\text { Solvent }\end{array}$ & $\begin{array}{c}\text { Bromine Content }(\%) \\
\text { Found Required }\end{array}$ & $\begin{array}{c}\text { Product } \\
\text { Yield\% }\end{array}$ \\
\hline $\mathbf{1} \rightarrow \mathbf{2}$ & 1 & 3.1 & $\begin{array}{c}\text { methanol/acetic acid } \\
(3 \% \mathrm{~V} / \mathrm{V})\end{array}$ & 34.94 & 35.37 & 83 \\
\hline $\mathbf{1} \rightarrow \mathbf{3}$ & 2 & 6.4 & $\begin{array}{c}\text { water/acetic acid } \\
(40 \% \mathrm{~V} / \mathrm{V})\end{array}$ & 51.69 & 52.26 & 73 \\
\hline
\end{tabular}

Table 2. Effect of current density on product yield ${ }^{1}$.

\begin{tabular}{|c|c|c|}
\hline \multirow{2}{*}{$\begin{array}{c}\text { Current } \\
\text { Density } \\
\mathrm{mA} / \mathrm{cm}^{2}\end{array}$} & $\begin{array}{c}|c| \\
\text { Product Yield \% } \\
\text { indandione }^{2}\end{array}$ & $\begin{array}{c}\text { 2,2-dibromo-1,3- } \\
\text { indandione }^{3}\end{array}$ \\
\hline 5 & 14 & 12 \\
15 & 24 & 21 \\
25 & 56 & 48 \\
50 & 83 & 73 \\
75 & 81 & 69 \\
\hline
\end{tabular}

${ }^{1}$ General conditions for electrolysis are similar to those mentioned in Table 1.

${ }^{2}$ Conditions for synthesis of 2-bromo-1,3-indandione are: solvent: methanol/acetic acid 3\% V/V, NaBr 1 mmol, 1,3-indandione 1mmol, current consumption: $299.1 \mathrm{C}$ or $3.1 \mathrm{Fmol}^{-1}$. 
${ }^{3}$ Conditions for synthesis of 2,2-dibromo-1,3-indandione are: solvent: water/acetic acid $40 \% \mathrm{~V} / \mathrm{V}, \mathrm{NaBr} 2 \mathrm{mmol}, 1,3$-indandione 1mmol, current consumption: $617.6 \mathrm{C}$ or $6.4 \mathrm{Fmol}^{-1}$.

\section{References and Notes}

1. Nematollahi, D.; Golabi, S. M. J. Electroanal. Chem., 1996, 405, 133.

2. Golabi, S. M.; Nematollahi, D. Bull. Electrochem., 1997, 13, 156.

3. Nematollahi, D.; Golabi, S M. Iranian J. Sci. Technol., 1997, 21, 121.

4. Golabi, S. M.; Nematollahi, D. J. Electroanal. Chem., 1997, 420, 127.

5. Golabi, S. M.; Nematollahi, D. J. Electroanal. Chem., 1997, 430, 141.

6. Nematollahi, D.; Golabi, S. M. Bull. Electrochem., 1998, 14, 97.

7. Nematollahi, D.; Golabi, S. M. J. Electroanal. Chem., 2000, 481, 208.

8. Nematollahi, D.; Golabi, S. M. Electroanalysis, accepted for publication.

9. Nematollahi, D.; Goodarzi, H. J. Electroanal. Chem., accepted for publication.

10. Spitulnik, Michael J. Synthesis, 1985, 299.

11. Vanags, G.; Pelchers, J. Doklady akad. Nauk. S.S.S.R., 1961, 140, 815.

12. Piers, E.; Grierson, J. R.; Lau, K. Cheuk; Nagakura, I. Can. J. Chem., 1982, 60, 210.

13. Gudriniece, E.; Vanags, G.; Strakov, A.; Neilands, O. Zhur. Obshchei Khim., 1959, 29, 1893.

14. Zelmens, V.; Vanags, G.; Krastina, Z. Latvijas P.S.R. Zinatnu Akad. Vestis, 1959, 7, 75.

15. Furdik, M.; Hrnciar, P.; Kucar, S. Acta Fac. Rerum Natur. Univ. Comeniae, Chim., 1966, 11, 37.

16. Paulins, J.; Karklina, A.; Gasjuna, L.; Gudriniene, E. Latv. PSR Zinat Akad. Vestis, Khim., 1979, 4, 490.

17. Mitsudera, H.; Konishi, K. Takeda Kenkyushoho., 1979, 38, 175.

18. Kosmrlj, J.; Kocevar, M.; Polanc, S. Synth. Commun., 1996, 26, 3583.

19. Sket, B.; Zupan, M. Synth. Commun., 1989, 19, 2481.

20. Bard, A. J.; Faulkner, L. R. Electrochemical Methods, Wiley, New York, 1980; pp 452-454.

21. Nematollahi, D.; Afkhami, A.; Zolfigol, M. A.; Akaberi, N. Bull. Electrochem., 2000, 16, 89.

22. Nematollahi, D., Akaberi, N. Bull. Electrochem., 2001, 17, 61.

23. Nematollahi, D.; Hesari, M. Microchem. J., in press.

24. Nyberg, K.; In Organic Electrochemistry, First Edition, Baizer, M. M.; Nyberg, K., eds.; Marcel Dekker: New York, 1973; p 720.

Sample Availability: All products reported in this paper are available from the authors.

(C) 2001 by MDPI (http://www.mdpi.org). Reproduction is permitted for noncommercial purposes. 